$\begin{array}{ll}\begin{array}{ll}\text { Australian Journal of } \\ \text { Crop Science }\end{array} & \text { A CS ISSN:1835-2707 }\end{array}$

doi: 10.21475/ajcs.21.15.07.p2902

\title{
Agronomic and qualitative performance of some special grain bean cultivars
}

\author{
Adailza Guilherme Cavalcante ${ }^{1 *}$, Leandro Borges Lemos ${ }^{1}$, Flávia Constantino Meirelles ${ }^{1}$, Vinicius Augusto \\ Filla $^{1}$, Alian Cássio Pereira Cavalcante ${ }^{2}$, Leonardo Angelo de Aquino ${ }^{3}$
}

\author{
${ }^{1}$ State University of São Paulo "Julio de Mesquita Filho", Jaboticabal, São Paulo, Brazil \\ ${ }^{2}$ Post-Graduate Program in Plant Science, Federal University of Viçosa, Viçosa, Minas Gerais, Brazil \\ ${ }^{3}$ Institute of Agricultural Sciences, Federal University of Viçosa, Rio Paranaíba Campus, Minas Gerais, \\ Brazil
}

\section{*Corresponding author: adailzacavalcante@gmail.com}

\begin{abstract}
In Brazil, bean consumption is predominated by grains like carioca, but special grains are gaining space on Brazilian tables and can be a source of income for producers. The objective of this study was to evaluate the agronomic and qualitative performance of common bean cultivars with special grains, aiming to identify those with productive potential and superior technological characteristics. The treatments consisted of nine bean cultivars with special grains: BRS Radiante, BRS Realce, BRS Pitanga, BRSMG Tesouro, BRS Marfim, BRSMG União, IAC Tigre, EPAMIG Ouro Vermelho, and EPAMIG Ouro da Mata. The agronomic (number of pods per plant, number of grains per pod, mass of 100 grains, and grain yield) and qualitative (sieve yield, crude protein, cooking time, percentage of imbibition before and after cooking, percentage of whole grains after cooking, and grain hydration capacity) attributes were evaluated. There were statistical differences between cultivars for the number of grains per pod and mass of 100 grains. The cultivars EPAMIG Ouro Vermelho, BRS Marfim, and BRS Pitanga presented the highest yields, with values of 2,907, 2,871, and 2,608 $\mathrm{kg} \mathrm{ha}^{-1}$, respectively. There was variability between cultivars for all qualitative attributes. The cultivars BRS Radiante, BRSMG Realce, BRSMG Tesouro, IAC Tigre, and EPAMIG Ouro Vermelho stood out with superior quality grains.
\end{abstract}

Keywords: Phaseolus vulgaris L., production component, productivity, technological characteristics of grains.

Abbreviations: NS_ no_till system, SY_ sieve yield, PC_ protein contente, CT _ cooking time, IBEC_soaking before cooking, IBAC_soaking after cooking, PGW_ percentage of whole grains after cooking, HT_time for grain hydration, HR_ hydration ratio.

Introduction

Bean grains (Phaseolus vulgaris L.) represent an important protein source in the diet and are the main product of the diet of more than 400 million people in the tropics. This importance is due especially to the quality and the lower cost of its protein in relation to products of animal origin (Buratto et al., 2009; Perina et al., 2010). Bean beans are also rich in carbohydrates, minerals, unsaturated fatty acids, dietary fiber and B vitamins (Silva et al., 2013).

In Brazil, beans are a traditional and important product in the population's diet where consumption is around $17,4 \mathrm{~kg}$ inhabitant ${ }^{-1}$ year $^{-1}$, and it is still the largest producer country in the world with 3.0 million tons of grains grown in an area of 2.9 million hectares. It is noteworthy that bean in Brazil, is a relatively cheap source of protein and it has high biological value when associated with cereals rich in sulfur amino acids (Bressani, 1993). In addition, it has importance in food security, being able to reduce malnutrition in developing countries (Reichert et al., 2015).

Despite the large availability of bean cultivars from various commercial groups, the main group of beans grown in Brazil is the carioca type (cream tegument with streaks or brown streaks) and because of this, receives greater attention from research and breeding programs. Special beans are all those that differ from the carioca and black types, and may be destined for export or not, with colored grains or not (Ferrari and Ramos Junior, 2015). This group is defined by having white, red, cream, yellow integument grains, among others, with absence or presence of streaks or streaks of other colors, and with grains of medium to large size (Blair et al., 2010).

Therefore, an alternative for the diversification of the cultivation and increase of income for the producers would be the adoption of the cultivation of beans of special grains, making available, in the internal and external market, a differentiated product and with greater added value, that is, a gourmet product. However, there is a lack of research and technical information on the performance of these cultivars in this commercial group, especially in relation to adaptation to cultivation sites and productive potential.

The importance of research on the adaptation and production stability of bean cultivars in different regions and environments is known (Pereira et al., 2012; Pereira et al., 2017). For cultivars from less widespread commercial groups, such as the special group, these studies are even more important, given the scarcity of information for these cultivars. Once launched, cultivars with wide adaptation and production stability lead to high economic benefits and income generation, reaching values close to US \$ 106 million (Silva and Wander, 2015). 
In addition to productivity and adaptation to the place of cultivation, attributes or technological / qualitative characteristics of the grains are desirable in bean cultivars to satisfy consumer requirements (Carbonell et al. 2010). According to Lemos et al. (2015), the commercial group to which a bean cultivar belongs brings together attributes related to the quality of grains, encompassing the technological characteristics represented by three properties: commercial, culinary and nutritional. Commercial quality means the type of grain formed by the characteristics of color, brightness, shape and size. Culinary quality is formed by the characteristics of hydration capacity, cooking time, color of the broth, flavor and texture. Nutritional quality is made up of crude protein, amino acids, carbohydrates, minerals, among others.

In view of the above, the objective was to evaluate the agronomic and qualitative performance of common bean cultivars with special grains, aiming to identify those with productive potential and with superior technological characteristics.

\section{Results and discussion}

\section{Agronomic atributes of the grains}

The precision of the results through the verification of the variation coefficient (VC), was $20.4 \%, 9.9 \%, 5.3 \%$ and $19.1 \%$, for the number of pods per plant, number of grains per pod, mass of 100 grains and grain yield, respectively (Table 1 ). These values demonstrated the proper conduct of the experiment, and the CVs found are below the limits considered acceptable for beans, where the number of pods per plant is $26.30 \%$, the number of grains per pod is $18.35 \%$, mass of 100 grains is $11.30 \%$ and grain yield is $24.86 \%$ (Oliveira et al., 2009).

It was verified for the components of production, number of grains per pod and mass of 100 grains, as well as for the grain yield that showed significant differences between bean cultivars. However, there was no difference between bean cultivars for the number of pods per plant that ranged from 9.5 to 14.7 obtained by cultivars BRSMG Realce and BRS Pitanga. For the number of grains per pod, EPAMIG Ouro Vermelho and BRSMG Tesouro obtained the highest values, compared to the others (Table 1).

As for the mass of 100 grains, IAC Tigre (38.5 g) and BRSMG União $(37.7 \mathrm{~g})$ cultivars had the highest values, differing significantly from the others (Table 1 ). It should be noted that the mass of 100 grains of the cultivars varied from 38.5 to 20.2 $\mathrm{g}$, obtained by IAC Tigre and BRS Pitanga, respectively. The size of the grains, expressed by the mass of 100 grains, varies according to the cultivar, being an attribute very influenced by the environment and of great importance for the consumer market (Carbonell et al., 2010; Perina et al., 2010). It is noteworthy that for special grain cultivars, no reference or citation was found in the literature that indicated the ideal value for this response variable.

According to Pereira et al. (2012) the mass of 100 grains, for the carioca type, preferred by the consumer must be above

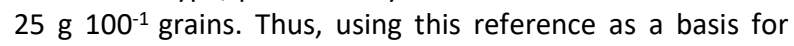
discussion, it can be inferred that all the cultivars studied showed extremely satisfactory performance regarding this attribute, except for BRSMG Tesouro and BRS Pitanga with 20.2 and $23 \mathrm{~g}$, respectively. However, these values are in accordance with that recommended by Embrapa for the two cultivars, which are 21.9 and $20.2 \mathrm{~g}$, respectively.

The bean cultivars differed for grain yield, which ranged from
1,798 to $2,907 \mathrm{~kg} \mathrm{ha}^{-1}$, being obtained by BRSMG Realce and EPAMIG Ouro Vermelho, respectively, that is, variation of $1,109 \mathrm{~kg}$ of grains which is equivalent to more of 18 bags of beans (Table 1). The cultivars BRS Ouro Vermelho, BRS Marfim and BRS Pitanga with 2,907, 2,871 and 2,608 $\mathrm{kg} \mathrm{ha}^{-1}$ stood out with the highest grain yield, showing the color of the red, mulatinho / light brown and purple tegument, respectively (Table 5 and 1). These values are close to the average for the State of São Paulo, which was $2,741 \mathrm{~kg} \mathrm{ha}^{-1}$ for beans of the Carioca type in the winter harvest with the use of irrigation (IEA, 2018), which shows the productive potential of these aforementioned cultivars.

Bean grain yield is the result of a combination of its components, such as the number of pods per plant or per unit area, the number of grains per pod and the mass of grains, being influenced by genetic and environmental factors (Fageria et al., 2015). Depending on the conditions, some production components may increase and others may decrease, facilitating the maintenance of grain productivity stability (Costa et al., 1983). As shown in Figure 1, during the conduction of the experiment, the climatic conditions remained in the ideal range for the vegetative and reproductive development of the bean (Portugal et al., 2015), a fact that is proven by the satisfactory grain yields obtained by the cultivars. The air temperature should not exceed $29^{\circ} \mathrm{C}$ $\mathrm{day}^{-1}$ to achieve high potential yields. Temperatures about 35 ${ }^{\circ} \mathrm{C}$ may cause losses in grain yield due to the abortion of flowers and pods, reduction of the number of grains per pod, grains with less dry mass and uneven distribution of pods in the plant. In addition, there is a reduction in the plant cycle, with less time for filling the grains (Silva et al., 2014).

Thus, the cultivar EPAMIG Ouro Vermelho obtained the highest grain yield due to the high number of grains per pod. The cultivar BRS Pitanga stood out in terms of grain productivity due to the higher number of pods per plant. The cultivar BRS Marfim also stood out in relation to grain productivity due to obtaining values for production components close to the experimental average.

\section{Qualitative atributes of the grains}

Regarding the qualitative attributes, in the study referring to the grain size of the cultivars, there was a significant difference in all classification screens (Table 2). For Carbonell et al. (2010) a bean cultivar must have $S Y \geq 12$ above $70 \%$, which represents coarse grains and with greater financial return to the producer. Thus, within this context, the cultivars BRS Radiante, EPAMIG Ouro da Mata, IAC Tigre, BRSMG Realce, BRSMG União and BRSMG Tesouro were highlighted. These cultivars also stood out in the percentage of grains retained in the sieve 13 (SY13), differing statistically from the others. It should also be noted that the cultivar BRS Radiante obtained the highest value of $S Y \geq 12$ (89.5\%), with $45.7 \%$ and $35.3 \%$, that is, $81.0 \%$ of grains retained in the sieves of sieves 14 (SY14) and 13 (SY13), respectively.

It was found that the bean cultivars showed significant differences regarding the crude protein content in the grains (Table 3). The cultivars EPAMIG Ouro Vermelho, BRS Radiante and BRSMG Tesouro stood out for this variable, obtaining values of $22.7 \%, 22.0 \%$ and $21.8 \%$, respectively, differing statistically from the others. This qualitative attribute can vary depending on the place of cultivation, the effect of genotype interaction by environment and the genetic variability between cultivars (Buratto et al., 2009; Ribeiro et al. 2008; Ribeiro et al., 2014). However, the average protein content was $21.1 \%$, corroborating the results obtained by 
Table 1. Number of pods per plant, number of grains per pod, mass of 100 grains and grain yield, of common bean cultivars with special type grains. Jaboticabal, SP - 2018 (1)

\begin{tabular}{|c|c|c|c|c|}
\hline \multirow[t]{2}{*}{ Cultivars } & Plant pods & Grains per pod & $\begin{array}{c}\text { Mass of } \\
100 \text { grains }\end{array}$ & Grain productivity \\
\hline & \multicolumn{2}{|c|}{ 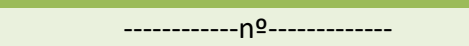 } & g & kg ha-1 \\
\hline BRSMG Realce & 9.5 & $4.7 \mathrm{c}$ & $31.7 \mathrm{c}$ & $1.798 \mathrm{~b}$ \\
\hline BRS Pitanga & 14.7 & $5.7 b$ & $20.2 \mathrm{~g}$ & $2.608 \mathrm{a}$ \\
\hline BRSMG Tesouro & 14.2 & $6.5 \mathrm{a}$ & $23.0 \mathrm{f}$ & $2.447 b$ \\
\hline BRSMG União & 12.0 & $5.7 b$ & 37.7 a & $2.140 \mathrm{~b}$ \\
\hline IAC Tigre & 12.5 & $4.7 \mathrm{c}$ & 38.5 a & $2.309 \mathrm{~b}$ \\
\hline EPAMIG Ouro Vermelho & 11.2 & $6.7 \mathrm{a}$ & $26.0 \mathrm{e}$ & $2.907 a$ \\
\hline EPAMIG Ouro da Mata & 12.7 & $5.5 \mathrm{~b}$ & $26.7 \mathrm{e}$ & $2.112 b$ \\
\hline
\end{tabular}

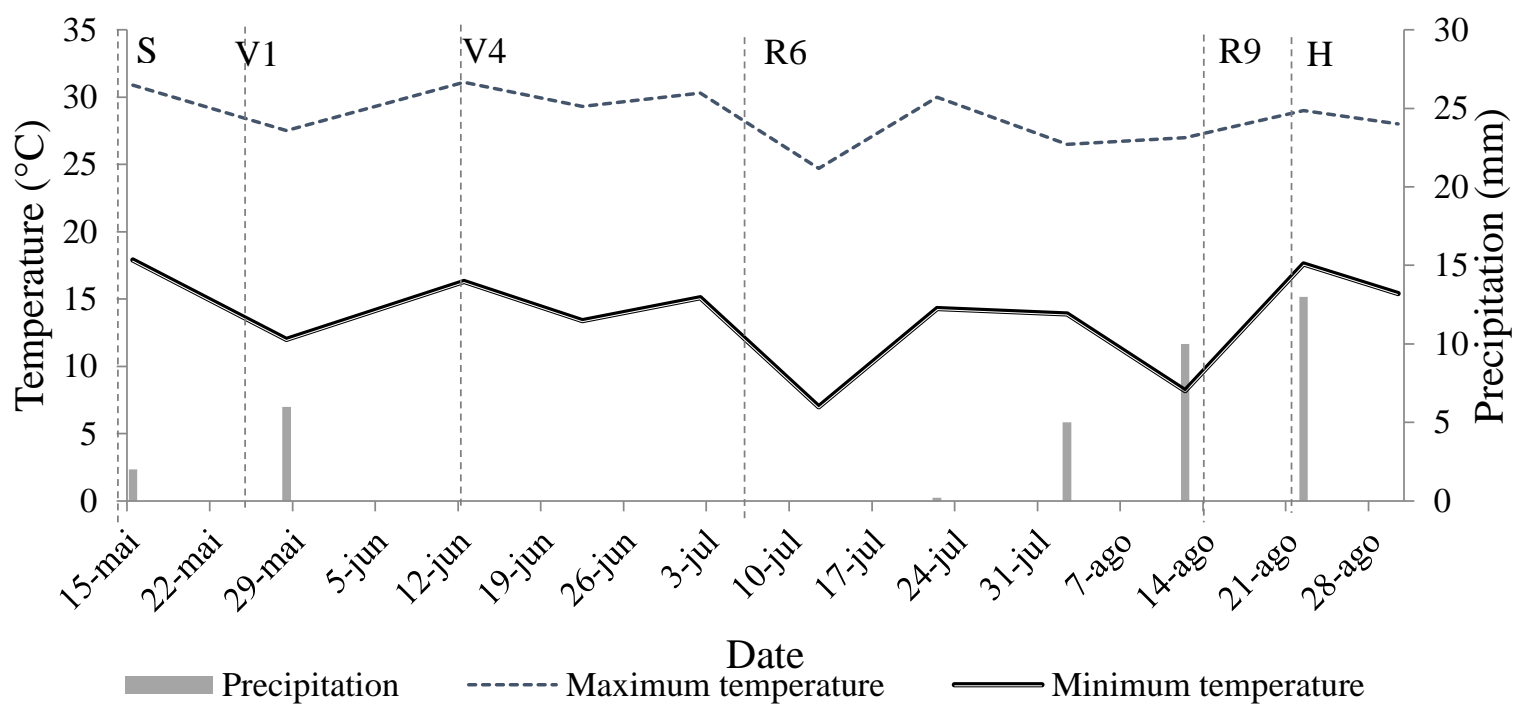

Figure 1. Climatic conditions recorded during the conduct of the experiment of special bean cultivars, in the winter harvest for the region of Jaboticabal, SP in 2018. S = sowing; V1 = emergency; V4 = third trefoil completely expanded; R6 = full flowering; R9 = physiological maturity; $C=$ harvest. Source: Agroclimatological station, Department of Exact Sciences UNESP, Jaboticabal, SP.

Table 2. Sieve yield (SY) of sieve 11,12,13, 14 and greater than and equal to 12, of common bean cultivars with special type grains. Jaboticabal, SP - $2018^{(1)}$.

\begin{tabular}{|c|c|c|c|c|c|}
\hline \multirow[t]{2}{*}{ Cultivars } & SY11 & SY12 & SY13 & SY14 & $S Y \geq 12$ \\
\hline & \multicolumn{5}{|c|}{--------------------------------------\%-------------------------------- } \\
\hline BRS Radiante & $1.5 \mathrm{c}$ & $8.6 \mathrm{c}$ & $35.3 \mathrm{a}$ & $45.7 \mathrm{a}$ & $89.5 \mathrm{a}$ \\
\hline BRSMG Realce & $9.5 \mathrm{~b}$ & $27.2 \mathrm{~b}$ & $34.5 \mathrm{a}$ & $19.6 \mathrm{c}$ & $81.2 \mathrm{a}$ \\
\hline BRS Pitanga & $21.0 \mathrm{a}$ & 50.9 a & $18.3 \mathrm{~b}$ & $0.0 \mathrm{f}$ & $69.2 \mathrm{~b}$ \\
\hline BRSMG Tesouro & $16.8 \mathrm{a}$ & 32.9 a & $33.1 \mathrm{a}$ & $7.5 \mathrm{e}$ & $73.7 \mathrm{~b}$ \\
\hline BRS Marfim & $27.6 \mathrm{a}$ & $45.0 \mathrm{a}$ & $5.9 \mathrm{~b}$ & $0.54 \mathrm{f}$ & $67.0 \mathrm{~b}$ \\
\hline BRSMG União & $4.1 \mathrm{c}$ & $19.9 \mathrm{~b}$ & $33.1 \mathrm{a}$ & $26.7 \mathrm{~b}$ & 79.7 a \\
\hline IAC Tigre & $9.1 \mathrm{~b}$ & $27.8 b$ & 38.6 a & $15.6 \mathrm{~d}$ & $82.5 \mathrm{a}$ \\
\hline EPAMIG Ouro Vermelho & $22.2 \mathrm{a}$ & $38.6 \mathrm{a}$ & $22.9 \mathrm{~b}$ & $2.0 \mathrm{f}$ & $66.0 \mathrm{~b}$ \\
\hline EPAMIG Ouro da Mata & $11.9 \mathrm{~b}$ & $40.7 \mathrm{a}$ & $45.4 \mathrm{a}$ & $2.0 \mathrm{f}$ & $84.2 \mathrm{a}$ \\
\hline Average & 13.6 & 32.2 & 29.7 & 13.3 & 77.0 \\
\hline Test $\mathrm{F}$ & $11.0^{*}$ & $6.77^{*}$ & $4.0^{*}$ & $62.0^{*}$ & $4.4^{*}$ \\
\hline CV (\%) & 38.0 & 31.1 & 39.7 & 29.3 & 10.2 \\
\hline
\end{tabular}

(1) Means followed by the same letter belong to the same group by the Scott-Knott test ( $p$-value $<0.05)$. CV (\%) = coefficient of variation; ns = not significant; ${ }^{*}=$ significant $(p<0.05)$. 
Table 3. Crude protein content (PC), cooking time (CT), soaking before cooking (IBEC), soaking after cooking (IBAC), and percentage of whole grains after cooking (PGW), of bean cultivars common with special type grains. Jaboticabal, SP - $2018^{(1)}$.

\begin{tabular}{|c|c|c|c|c|c|}
\hline \multirow[t]{2}{*}{ Cultivars } & PC & CT & IBEC & IBAC & PGW \\
\hline & $\%$ & $\min : s e g$ & \multicolumn{3}{|c|}{------------------\%"----------------- } \\
\hline BRS Radiante & $22.0 \mathrm{a}$ & $26: 03 b$ & $103.48 \mathrm{~b}$ & $143.68 c$ & $88.65 \mathrm{a}$ \\
\hline BRS Realce & $21.1 \mathrm{~b}$ & $25: 03 \mathrm{~b}$ & $105.36 \mathrm{a}$ & $143.48 \mathrm{c}$ & $88.36 \mathrm{a}$ \\
\hline BRS Pitanga & $20.2 \mathrm{c}$ & $23: 37 c$ & $98.21 \mathrm{~d}$ & $152.23 \mathrm{~b}$ & $90.23 a$ \\
\hline BRS Tesouro & $21.8 \mathrm{a}$ & $20: 03 d$ & $98.39 \mathrm{~d}$ & $158.62 \mathrm{a}$ & $80.38 b$ \\
\hline BRS Marfim & $21.2 \mathrm{~b}$ & $23: 33 \mathrm{c}$ & $94.39 \mathrm{e}$ & $142.93 \mathrm{c}$ & $74.31 \mathrm{~b}$ \\
\hline BRSMG União & $20.6 \mathrm{c}$ & $28: 05$ a & $103.84 \mathrm{~b}$ & $149.54 \mathrm{~b}$ & $69.49 c$ \\
\hline IAC Tigre & $20.8 \mathrm{~b}$ & $19: 04 d$ & $100.66 \mathrm{c}$ & $141.63 \mathrm{c}$ & $88.88 \mathrm{a}$ \\
\hline EPAMIG Ouro Vermelho & $22.7 \mathrm{a}$ & $20: 12 d$ & $104.37 \mathrm{~b}$ & $146.61 \mathrm{c}$ & $68.93 c$ \\
\hline EPAMIG Ouro da Mata & $20.2 \mathrm{c}$ & $19: 37 d$ & $101.07 \mathrm{c}$ & $140.31 \mathrm{c}$ & $78.02 \mathrm{~b}$ \\
\hline Average & 21.1 & $22: 48$ & 101.17 & 146.56 & 80.80 \\
\hline Test $\mathrm{F}$ & $8.17^{*}$ & $13.82^{*}$ & $78.17^{* *}$ & $5.73^{* *}$ & $21.88^{* *}$ \\
\hline CV (\%) & 3.2 & 7.44 & 0.69 & 2.92 & 3.94 \\
\hline
\end{tabular}

Table 4. Regression equation between the time for grains hydration, amount of water absorbed by the grains, time for grain hydration (HT) and the hydration ratio (HR) of common bean cultivars with special type grains. Jaboticabal, SP $-2018^{(1)}$.

\begin{tabular}{|c|c|c|c|c|}
\hline Cultivars & Regression equation (2) & \multicolumn{3}{|c|}{$\mathrm{h}: \min$} \\
\hline BRS Radiante & $y=-0.00006 x^{2}+0.11107 x-1.00334$ & $0.99^{* *}$ & $16: 03 \mathrm{a}$ & $2.0 \mathrm{a}$ \\
\hline BRSMG Realce & $y=-0.00006 x^{2}+0.11778 x-3.38630$ & $0.98^{* *}$ & $15: 18 \mathrm{a}$ & $2.0 \mathrm{a}$ \\
\hline BRS Pitanga & $y=-0.00008 x^{2}+0.12387 x-0.19114$ & $0.98^{* *}$ & $13: 13 b$ & $1.9 \mathrm{~b}$ \\
\hline BRSMG Tesouro & $y=-0.00008 x^{2}+0.11937 x+6.83594$ & $0.92^{* *}$ & $13: 32 b$ & $1.9 \mathrm{~b}$ \\
\hline BRS Marfim & $y=-0.00006 x^{2}+0.10745 x+1.84444$ & $0.99^{* *}$ & $14: 55 a$ & $1.9 \mathrm{~b}$ \\
\hline BRSMG União & $y=-0.00007 x^{2}+0.12305 x+0.32970$ & $0.99^{* *}$ & $13: 55 b$ & $2.0 \mathrm{a}$ \\
\hline IAC Tigre & $y=-0.00005 x^{2}+0.10420 x-2.45236$ & $0.98^{* *}$ & $15: 22 \mathrm{a}$ & $2.0 \mathrm{a}$ \\
\hline EPAMIG Ouro Vermelho & $y=-0.00009 x^{2}+0.12224 x+11.46168$ & $0.82^{* *}$ & $11: 47 c$ & $2.0 \mathrm{a}$ \\
\hline EPAMIG Ouro da Mata & $y=-0.00004 x^{2}+0.08613 x+2.51407$ & $0.97^{* *}$ & $15: 46 a$ & $2.0 \mathrm{a}$ \\
\hline Average & ---- & --- & $14: 03$ & 2.0 \\
\hline Test $\mathrm{F}$ & ---- & --- & $14.95^{* *}$ & $5.2^{* *}$ \\
\hline CV (\%) & ---- & -. & 5.61 & 9 \\
\hline
\end{tabular}

${ }^{(1)}$ Means followed by the same letter belong to the same group by the Scott-Knott test (p value $\left.>0.05\right) . \mathrm{CV}$ : coefficient of variation. ${ }^{\text {** }}$ significant at $1 \%$ probability. ${ }^{(2)} \mathrm{x}=$ time for hydration (hours) and $y=$ amount of water absorbed (ml).

Table 5. Information regarding common bean cultivars with special grains. Jaboticabal, SP - 2018.

\begin{tabular}{|l|l|l|l|l|}
\hline Cultivares & Owned institution (1) & Grouth habit & Cycle (days) & Integument description \\
\hline BRS Radiante & EMBRAPA & Type II & 80 & Brindle - cream tegument with streaks or red stripes \\
\hline BRSMG Realce & EMBRAPA & Type I & $67-75$ & Brindle - cream tegument with streaks or red stripes \\
\hline BRS Pitanga & EMBRAPA & Type II & $80-85$ & Purple \\
\hline BRSMG Tesouro & EMBRAPA & Type II & $80-90$ & Purple \\
\hline BRS Marfim & EMBRAPA & Type II & $85-90$ & Mulatinho - light brown coat \\
\hline BRSMG União & EMBRAPA & Type III & 77 & Jalo - yellow coat \\
\hline IAC Tigre & IAC & Type II & 85 & Brindle - cream coat with spots light brown \\
\hline EPAMIG Ouro Vermelho & EPAMIG & Type II & $80-90$ & Red \\
\hline EPAMIG Ouro da Mata & EPAMIG & Type II & $85-90$ & Red \\
\hline
\end{tabular}

${ }^{(1)}$ Brazilian Agricultural Research Corporation (EMBRAPA); Campinas Agronomic Institute (IAC); Minas Gerais Agricultural Research Company (EPAMIG). ${ }^{(2)}$ According to the release bulletin by the bodies responsible for the cultivar.

Ramos Junior et al. (2005), Farinelli and Lemos (2010), Perina et al. (2010) and Mingotte et al. (2013). Regarding cooking time, cultivars obtained an average of 22:48 minutes: seconds, ranging from 19:04 to 28:05 minutes: seconds (Table 3). This difference of 09 minutes can be considered expressive or high, within the context of energy consumption in terms of gas and time for food preparation. The cultivars IAC Tigre, EPAMIG Ouro da Mata, BRS Tesouro and EPAMIG Ouro Vermelho showed the lowest values for cooking, between 19:04 and 20:12 minutes: seconds, differing statistically from the others. According to Proctor and Watts (1987), the cooking time between 16 to 20 minutes is classified as having medium resistance to cooking. For these same authors, the other bean cultivars were classified as normal cooking resistance, that is, they obtained values in the range of 21 to 28 minutes. However, it should be noted that all cultivars were within the cooking time range recommended by Ramalho and Abreu (2006), which is less than 30 minutes.

There were statistical differences between bean cultivars for qualitative attributes percentage of soaking before cooking (IBEC), percentage of soaking after cooking (IBAC) and percentage of whole grains after cooking (PGW) (Table 3). The cultivars BRS Realce and BRS Tesouro stood out with the highest values of PIBEC and PIBAC, respectively. The highlights for PGW were the cultivars BRS Pitanga, IAC Tigre, BRS Radiante and BRS Realce. It was also observed that the BRS Realce cultivar that obtained the highest PIBEC was not the one that had the shortest cooking time, contrary to the 
results found by Dalla Corte et al. (2003) and Rodrigues et al. (2005), who mentioned that the cooking time depends on the water absorption capacity. However, the cultivar IAC Tigre showed the shortest cooking time and stood out among the materials that obtained high PGW, this aspect being very interesting for both the packaging industry and the consumer. The regression equations between the hydration time and the amount of water absorbed by the beans of the bean cultivars (Table 4), showed that the period necessary for maximum hydration ranged from 11:47 hours (EPAMIG Ouro Vermelho) to 16:03 hours (BRS Radiante). Therefore, there was a difference of 5:06 hours, which can be considered a high value. The cultivars that had the longest periods were BRS Radiante, EPAMIG Ouro da Mata, IAC Tigre, BRSMG Realce and BRS Marfim with values of 16:03, 15:46, 15:22, 15:18 and 14:55 hours, respectively.

The methodology used, described in Normative Instruction No. 25 of 05/23/2006 of the Ministry of Agriculture, Livestock and Supply-MAPA (Brazil, 2006), considers as standard the time of 16 hours of hydration of the grains in distilled water, the cultivars showed satisfactory performance for the grains to obtain complete water absorption. However, as beans are usually left to steep (imbibition) the night before preparation, for a period of approximately 12 hours (Ramos Junior et al., 2005), satisfactory performance was observed only for EPAMIG Ouro Vermelho cultivar.

As for the hydration ratio, it was found that there were statistical differences between the cultivars evaluated (Table 4). However, these values were close to two (2.0), that is, the grains absorbed a water mass similar to its initial mass, which shows satisfactory performance regarding this attribute (Ramos Junior et al., 2005; Farinelli and Lemos 2010; Mingotte et al. 2013).

Thus, regarding the qualitative attributes, it can be inferred that the cultivar BRS Radiante stood out for presenting the highest RP $\geq 12$, RP 13 and RP14, that is, coarse grains, with a high content of crude protein and PGW. The cultivar BRSMG Realce stood out for obtaining the highest value for PIBEC, as well as high RP $\geq 12$ and PGI. The BRSMG Tesouro cultivar also stood out, presenting high PIBAC, high crude protein content and short cooking time. The cultivar IAC Tigre stood out due to the shorter cooking time, high RP $\geq 12$ and PGW. It also stood out for cultivating EPAMIG Ouro Vermelho due to the higher crude protein content, as well as the reduced cooking time and the lower HT.

\section{Materials and methods}

\section{Experimental site}

The experiment was conducted at the Teaching, Research and Extension Farm (FEPE) of the Faculty of Agricultural and Veterinary Sciences of the São Paulo State University (UNESP), located in the municipality of Jaboticabal, São Paulo State, Brazil. According to the Köppen classification, the predominant climate in the region is of the Aw type, humid tropical with rainy season in summer and dry in winter. The soil in the experimental area is classified as a clayey red latosol (Embrapa, 2013). The climatic data during the conduct of the experiment are shown in Figure 1.

The chemical attributes and the granulometry of the soil were determined in the layer 0.00-0.20 $\mathrm{m}$ deep, before sowing the bean and the results obtained were: $\mathrm{pH}(\mathrm{CaCl} 2)=6.1 ; \mathrm{MO}=$ $22 \mathrm{~g} \mathrm{dm}^{-3} ; \mathrm{P}$ (resin) $=87 \mathrm{mg} \mathrm{dm}^{-3} ; \mathrm{K}=9.0 \mathrm{mmolc} \mathrm{dm}^{-3} ; \mathrm{Ca}=48$ mmolc dm ${ }^{-3} ; \mathrm{Mg}=20 \mathrm{mmolc} \mathrm{dm}^{-3} ; \mathrm{S}=10 \mathrm{mg} \mathrm{dm}^{-3} ; \mathrm{B}=0.25$ $\mathrm{mg} \mathrm{dm}{ }^{-3} ; \mathrm{Cu}=1.0 \mathrm{mg} \mathrm{dm}^{-3} ; \mathrm{Fe}=20 \mathrm{mg} \mathrm{dm}^{-3} ; \mathrm{Mn}=23 \mathrm{mg} \mathrm{dm}^{-}$
3; $\mathrm{Zn}=4.0 \mathrm{mg} \mathrm{dm}^{-3} ; \mathrm{H}+\mathrm{Al}=25 \mathrm{mmolc} \mathrm{dm}{ }^{-3} ; \mathrm{CTC}=102 \mathrm{mmolc}$ $\mathrm{dm}^{-3} ; \mathrm{V}=75 \%$; clay $=540 \mathrm{~g} \mathrm{~kg}^{-1} ;$ silt $=230 \mathrm{~g} \mathrm{~kg}^{-1}$ and sand $=$ $230 \mathrm{~g} \mathrm{~kg}^{-1}$.

\section{Treatments and experimental design}

The experimental design was in randomized blocks, with nine treatments and four replications. The treatments consisted of nine bean cultivars with special grains: BRS Radiante, BRS Pitanga, BRS Realce, BRSMG Tesouro, BRS Marfim, BRSMG União, IAC Tigre, EPAMIG Ouro Vermelho and EPAMIG Ouro da Mata (Table 5). Each experimental plot consisted of five lines with five meters in length, spaced at 0.45 meters, being considered useful area to the three central lines, disregarding 0.5 meters from each end.

The experimental area was in the first year of adoption of the no-tillage system, being implanted through soil scarifing on December 06, 2017, followed by the application of lime (dose of $1 \mathrm{t} \mathrm{ha}^{-1}$ ) based on previous soil analysis, with subsequent incorporation by one disk plow and two leveling harrows. The crop prior to bean was millet (Pennisentum americanum L.), cultivar ADR - 300, sowed on December 13, 2017, using $14 \mathrm{~kg}$ $\mathrm{ha}^{-1}$ of seeds with a spacing of $0.45 \mathrm{~m}$ between rows. The millet culture was desiccated at 60 days after emergence, when it was with the panicles, using glyphosate at a dose of 2 $\mathrm{L}$ ha-1 ${ }^{-1}$ of the commercial product. Ten days after the herbicide application, millet was managed using a mechanized plant desintegrator.

The bean cultivars were sown on May 18, 2018, distributing 12 seeds per meter of furrow, with a spacing of $0.45 \mathrm{~m}$, standardizing a final population of 245,000 plants ha-1 for all plots. The cultivation was classified as winter bean due to the sowing time and use of irrigation. A conventional sprinkler irrigation system was used, with the irrigation frequency every 4 days, applying a 10 to $20 \mathrm{~mm}$ of water depth according to the crop's need. The total water depth applied was $550 \mathrm{~mm}$ (Pavani et al., 2008).

\section{Cultural management and treatment}

The sowing and sidedress fertilizations were carried out according to the technical recommendations of Ambrosano et al. (1997). The fertilization in the sowing furrow was carried out using a dose of $350 \mathrm{~kg} \mathrm{ha}^{-1}$ of the formulated $04-28-10$ (0.3\% B, 4\% Ca, 0.01\% Mo, 5\% S and 1.2\% Zn), corresponding to the doses of 14,98 and $35 \mathrm{~kg} \mathrm{ha}^{-1}$ of $\mathrm{N}, \mathrm{P}_{2} \mathrm{O}_{5}$ and $\mathrm{K}_{2} \mathrm{O}$, respectively. The cover fertilizations were carried out in two stages: the first at the phenological stage V4-4 (fourth formed and expanded trifoliate leaf) which consisted of $60 \mathrm{~kg} \mathrm{ha}^{-1}$ of $\mathrm{N}$ and $20 \mathrm{~kg} \mathrm{ha}^{-1}$ of $\mathrm{K}_{2} \mathrm{O}$ via formulated fertilizer 30-00-10 and the second at stage V4-6 (sixth trifoliate leaf formed and expanded) of $60 \mathrm{~kg} \mathrm{ha}^{-1}$ of $\mathrm{N}$, via urea. The fertilizers were applied to the soil surface in a continuous thread $10 \mathrm{~cm}$ from the crop line, followed by irrigation with a $15 \mathrm{~mm}$ water depth.

For the control of weeds, applications of the herbicides Smetolachlor were carried out at a dose of $1.2 \mathrm{~kg} \mathrm{ha}^{-1}$ in preemergence and in post-emergence Cletodim (108 $\mathrm{g} \mathrm{ha}^{-1} \mathrm{of}$ ia) was used in stage V3 (emission of the first trifoliate leaf) and in V4 (emission of the third trifoliate leaf) of Bentazone + Imaxomoxy ( $600+28 \mathrm{~g}$ ha- ${ }^{1}$ of ia). Phytosanitary management was carried out by monitoring pests and diseases, spraying acetamiprid (300 $\mathrm{g} \mathrm{ha}^{-1}$ a.i.) on July 6; acetamiprid + pyriproxifem $\left(300+100 \mathrm{~g} \mathrm{ha}^{-1}\right.$ a.i. $)$ on July 5 ; thiamethoxam + lambda-cyhalothrin (100 mL ha-1) on July 10; piraclostrobin + thiamethoxam + lambda - cyhalothrin $\left(40 \mathrm{~g}+100 \mathrm{~mL} \mathrm{ha}{ }^{-1}\right.$ of a.i.) on July 26 . 


\section{Variables analyzed}

The agronomic attributes were determined from the physiological maturity of the pods (R9). The production components were evaluated: number of pods per plant, number of grains per pod and mass of 100 grains by collecting 10 consecutive plants in the cultivation line in the useful area of each plot. As for grain productivity, it was carried out by plucking the plants in the useful area of the plot, with drying in full sun and subsequent mechanized trail, standardizing the moisture content of the grains to $13 \%$ b.u.

The determination of qualitative attributes started with the sieve yield (SY), where grain samples from each experimental plot were submitted to the set of number 11 (11/64"in.), 12 (12/64) oblong sieves. "In.), 13 (13/64" in.) And 14 (14/64 "in.) Stirring for one minute. The values presented were used to calculate the percentage of grains, through the relationship between the mass of grains retained in each sieve and the mass of the total sample of each repetition. A sieve yield greater than or equal to 12 ( $S Y \geq 12$ ) was also performed, with the sum of the sieves with oblong sieves 12,13 and 14 .

The crude protein content (\%) was obtained by the contente of nitrogen $(\mathrm{N})$ contained in the grains and the calculation was made: $\mathrm{PC}=($ total $\mathrm{N} \times 6.25)$ where, $\mathrm{PC}=$ crude protein content in the grains $\left(\mathrm{g} \mathrm{kg}^{-1}\right)$ and total $\mathrm{N}=\mathrm{N}$ content in the grains. The cooking time was determined with the aid of the Mattson cooker. For this determination, the grains were previously hydrated in deionized water for 16 hours.

The percentage of imbibition before (IBEC) and after cooking (IBAC) were obtained using the methods described by GarciaVela and Stanley (1989) and by Plhak et al. (1989). For this, approximately $30 \mathrm{~g}$ of uniform and whole grains were sampled, obtaining the dry mass of the grains (DM) in the initial stage of the analytical procedure. The grains were soaked in $100 \mathrm{ml}$ of deionized water in a $250 \mathrm{ml}$ beaker for 16 hours at room temperature. For IBEC, after this period, the beans were removed and quickly dried with paper towels and then weighed, obtaining the wet grain mass (MU) and the percentage of imbibition, determined by the formula: $\mathrm{IBEC}=$ [(MU - MS) / MS ] x 100.

For IBAC, after 16 hours of soaking, the $30 \mathrm{~g}$ of grains were heated in an electric hot plate for one hour after the beginning of the boil, with replacement of evaporated water, when necessary. The grains (whole and fragmented) were drained and weighed, obtaining the wet mass after cooking (MUc) and determined by the formula: IBAC $=[(\mathrm{MUc}-\mathrm{MS})$ / MS] x 100.

From the sample from IBAC, the percentage of whole grains after cooking (PGW) was obtained. The beans, after cooking, were counted in their entirety $(T)$ and separated into two portions: whole (W) and broken (B). From that count, the PGW was then calculated using the formula: $P G W=[(T-B) /$ T] $x 100$.

The hydration capacity was quantified in samples of $50 \mathrm{~g}$ placed in deionized water for 16 hours, evaluating the volume of water not absorbed by the grains every two hours, pouring it from the beaker into a beaker. At the end of the expected hydration time, the water was completely drained and the grains were weighed. Then the hydration ratio was determined, determined by the ratio between the mass after hydration and the initial mass of the grains. The study of polynomial regression between time (hours) and hydration capacity $(\mathrm{mL})$ was performed to determine the time required for maximum grain hydration.

The data were submitted to analysis of variance by the $F$ test and the means grouped by the Scott-Knott test. Polynominal regression analysis was used for time data for maximum grain hydration. The analyzes of variance were performed with the aid of the SISVAR statistical program (Ferreira, 2014).

\section{Conclusions}

There is variability between special grain cultivars in terms of agronomic and qualitative attributes.

The most productive cultivars were EPAMIG Ouro Vermelho, BRS Marfim and BRS Pitanga. The cultivars BRS Radiante, BRSMG Realce, BRSMG Tesouro, IAC Tigre and EPAMIG Ouro Vermelho stood out for the qualitative attributes of the grains.

\section{Acknowledgements}

We are grateful to the Coordination for the Improvement of Higher Education Personnel (CAPES), financing code 001 for granting a doctoral scholarship to the first author.

\section{References}

Ambrosano EJ, Wutke EB, Bulisani EA, Cantarella BH (1997). Feijão. In: Recomendação de adubação e calagem para o Estado de São Paulo. 2.ed. Raij V, Cantarella BH, Quaggio JÁ, Furlani AMC (Ed.), IAC, Campinas. p. 194-195. (Boletim Técnico, 100).

Blair MW, González LF, Kimani PM, Butare L (2010). Genetic diversity, inter-gene pool introgression and nutritional quality of common beans (Phaseolus vulgaris L.) from Central Africa. Theorical Appl. Genet. 121(2):237-248.

Buratto JS, Moda-Cirino V, Scholz MBS, Langame DEM, Fonseca Júnior N, Prete CEC (2009). Variabilidade genética e efeito do ambiente para o teor de proteína em grãos de feijão. Acta Sci Agron. 31(4):593-597.

Bressani R (1993) Grain quality of common beans. Food Rev Int. 9(2):237-297.

Carbonell, SAM, Chioratto AF, Gonçalves JGR, Perina EF and Carvalho CRL (2010). Tamanho de grão comercial em cultivares de feijoeiro. Ciên Rural, 40(10):2067-2073.

Costa JGC, Kohashi-Shibata J, Colin SM (1983). Plasticidade no feijoeiro comum. Pesqui. Agropecu. Bras., 18(2):159-167.

Dalla Corte A, Moda-Cirino V, Sholz MBS, Destro D (2003). Enviroment effect on grain quality in early commom bean cultivars and lines. Crop Breed. Appl. Biotechnol. 3(3):193202.

Embrapa (Empresa Brasileira de Pesquisa Agropecuária). 2013. Centro Nacional de Pesquisa de Solos. Sistema brasileiro de classificação de solos. 3. ed. Embrapa, Brasília. $353 \mathrm{pp}$.

Fageria NK, Stone LF, Santos AB, Carvalho MCS (2015). Nutrição mineral do feijoeiro. Brasília: Embrapa, 394.

Farinelli R, Lemos LB (2010). Qualidade nutricional e tecnológica de genótipos de feijão cultivados em diferentes safras agrícolas. Bragantia, 69(3):759-764.

Ferreira DF (2014). Sisvar: a guide for its bootstrap procedures in multiple comparisons. Ciênc. e Agrotec., 38(2):109-112.

Ferrari S, Ramos Júnior EU (2015) Tipos especiais de feijão. In: arf O, Lemos LB, Soratto RP, Ferrari S, (eds). Aspectos gerais da cultura do feijão Phaseolus vulgaris L. Botucatu: FEPAF, 370-386.

Garcia-Vela LA, Stanley DW (1989). Water holding capacity in hard-to-cook beans (Phaseolus vulgaris L.): effect of $\mathrm{pH}$ and ionic strength. J. Food Sci, 54(4):1080-1081. 
IEA. Instituto de Economia Agrícola. Previsões e estimativas das safras agrícolas do estado de São Paulo, segundo levantamento, ano agrícola 2017/18 e levantamento final, ano agrícola 2016/17, novembro de 2017. Análises e Indicadores do Agronegócio, v.13, n.2, p.1-13, fevereiro 2018.

Lemos LB, Mingotte FLC, Farinelli R (2015) Cultivares. In: Arf $\mathrm{O}$, Lemos LB, Soratto, RP, Ferrari S, (eds). Aspectos gerais da cultura do feijão Phaseolus vulgaris L. Botucatu: FEPAF,181207.

Mingotte FLC, Guarnieri CCDO, Farinelli R, Lemos LB (2013). Desempenho produtivo e qualidade pós-colheita de genótipos de feijão do grupo comercial carioca cultivados na época de inverno-primavera. Bioscience J., 29(5):11011110.

Oliveira RL, Muniz JÁ, Andrade MJB, Reis RL (2009). Precisão experimental em ensaios com a cultura do feijão. Ciênc. Agrotec., 33(1):113-119.

Pavani LC, Lopes AS, Galbeiro RB (2008). Manejo da irrigação na cultura do feijoeiro em sistemas plantio direto e convencional. Eng. Agríc., 28(1):12-21.

Pereira HS, Almeida VM, Melo LC, Wendland A, Faria LC, Peloso MJD, Magaldi MCS (2012). Influência do ambiente em cultivares de feijoeiro-comum em cerrado com baixa altitude. Bragantia, 71(2):165-172.

Pereira HS, Alvares RC, Silva FC, Faria LC, Melo LC (2017). Genetic environmental and genotype $x$ environment interaction effects on the common bean grain yield and commercial quality. Semina: Ciên. Agrár., 38(3):1241-1250.

Perina EF, Carvalho CRL, Chiorato AF, Gonçalves JGR, Carbonell SAM (2010). Avaliação da estabilidade e adaptabilidade de genótipos de feijoeiro (Phaseolus vulgaris L.) baseada na análise multivariada da "performance" genotípica. Ciênc. e Agrotec., 34(2):398406.

Portugal JR, Peres AR \& Rodrigues RAF (2015) Aspectos climáticos no feijoeiro. In: Arf O, Lemos LB, Soratto RP \& Ferrari S. Aspectos gerais da cultura do feijão. 1. ed. Botucatu: FEPAF , p. 65-75.
PIhak LC, Caldwell KB, Stanley DW (1989). Comparision of methods used to characterize water imbibition in hard-tocook beans. J. Food Sci., 54(2):326-336.

Proctor JR and Watts BM (1987). Development of a modifi ed Mattson bean cooker procedure based on sensory panel cookability evaluation. Can. Inst. Food Sci. j., 20(1):9-14.

Ramalho MAP, Abreu AFB, Cultivares. In: Vieira C, Paula Junior TJ, Borém A, (eds). Feijão. 2.ed. Viçosa: UFV, 415-436 (2006).

Ramos Junior EU, Lemos LB, Silva TRB (2005) Componentes da produção, produtividade de grãos e características tecnológicas de cultivares de feijão. Bragantia, 64(1):75-82.

Reichert JM, Rodrigues MF, Awe GO, Riquelme UFB, Kaiser DR, Reinert DJ (2015) Common bean in highly variable weather conditions, on sandy soils, and food security in a subtropical environment. Food and Energy Security, 4(3):219-237.

Ribeiro, N.D, Antunes IF, Poersch NL, Rosa SSD, Teixeira MG, Gomes ALDS (2008). Potencial de uso agrícola e nutricional de cultivares crioulas de feijão. Ciênc. Rural, 38(3):628-634.

Ribeiro, N.D, Domingues LDS, Gruhn EM, Zemolin AEM, Rodrigues JDA (2014). Desempenho agronômico e qualidade de cozimento de linhagens de feijão de grãos especiais. Rev. Ciênc. Agronômica, 45(1):92-100.

Rodrigues JA, Ribeiro ND, Cargnelutti Filho A, Trentin M, Londero PMG (2005). Qualidade para o cozimento de grãos de feijão obtidos em diferentes épocas de semeadura. Bragantia, 64(3):369-376.

Silva MO, Brigide P, Canniatti-Brazaca SG (2013). Caracterização da composição centesimal e mineral de diferentes cultivares de feijão comum crus e cozidos. Alimentos e Nutrição, 24(3):339-346.

Silva OF, Wander AE. 2015. Viabilidade econômica da cultivar de feijão-comum BRS Estilo. Rev. Bras. Desenvolv. Regional, 3(1):223-242.

Silva SC, Didonet AD \& Morais AC (2014) Clima. In: EMBRAPA. Feijão: o produtor pergunta, a Embrapa responde. 2 ed. rev. e ampl. - Brasília, DF: Embrapa, 247 pp. 